\title{
Platform design for extraction and isolation of Bromelain: Complex formation and precipitation with carrageenan
}

\author{
Débora A. Campos ${ }^{a}$, Nadia Woitovich Valetti ${ }^{b}$, Ana Oliveira ${ }^{a}$, \\ Lorenzo M. Pastrana-Castro $^{c}$, José A. Teixeira ${ }^{d}$, Maria Manuela Pintado ${ }^{a, *}$, \\ Guillermo Picó ${ }^{\mathrm{b}}$
}

\author{
a CBQF-Centro de Biotecnologia e Química Fina-Laboratório Associado, Escola Superior de Biotecnologia, Universidade Católica Portuguesa/Porto, Rua \\ Arquiteto Lobão Vital Apartado 2511, 4202-401, Porto, Portugal \\ ${ }^{\mathrm{b}}$ IPROBYQ-Institute of Biotechnological and Chemistry Processes, Faculty of Biochemical and Pharmaceutical Sciences and CONICET, National University of \\ Rosario, Suipacha 570, (S2002RLK) Rosario, Argentina \\ ' INL-International Iberian Nanotechnology Laboratory, 4710-330, Braga, Portugal \\ d Centro de Engenharia Biológica, Universidade do Minho, Campus Gualtar, 4710-057, Braga, Portugal
}

\section{A R T I C L E I N F O}

\section{Article history:}

Received 17 October 2016

Received in revised form

19 December 2016

Accepted 20 December 2016

Available online 23 December 2016

\section{Keywords:}

Protein complex

Enzyme mechanism

Carrageenan

Polyelectrolytes

Bromelain

\begin{abstract}
A B S T R A C T
The main objective of this work was to investigate for the first time the molecular mechanism of complex formation between bromelain (a positively charged enzyme) and carrageenan (a natural strong polyelectrolyte, negatively charged) using spectroscopy techniques and thermodynamic approaches. The Bromelain-Carrageenan complex showed a maximal non-solubility at $\mathrm{pH}$ around 5.1. The solubility was dependent on $\mathrm{pH}$ and ionic strength of the medium. To re-dissolve the formed complex, the $\mathrm{pH}$ was changed and $500 \mathrm{mM}$ of $\mathrm{NaCl}$ was added to the initial solution, proving the columbic mechanism for the formation of non-soluble complex. The formation of the carrageenan-bromelain complex increased in $8{ }^{\circ} \mathrm{C}$ the enzyme thermal stability, while its biological activity was not modified. The amount of total enzyme recovered in solution after precipitation with around $0.08 \% \mathrm{w} / \mathrm{v}$ of carrageenan was $85-90 \%$.
\end{abstract}

(C) 2016 Elsevier Ltd. All rights reserved.

\section{Introduction}

Nowadays, several techniques frequently used to isolate and purify enzymes, namely chemical precipitations and extractions approaches using organic solvents have high costs, low purity rate and are not eco-friendly [1]. In many biotechnological industries (food, medical and pharmaceutical) the selective separation of an enzyme from fermentation broths, animal and vegetal sources has been a primary research interest for downstream processing operations [2]. The extraction of an enzyme from a crude extract could be very difficult not only due to low protein concentration but also the presence of contaminants with similar physical properties in the same solution $[3,4]$. Considering all aforementioned challenges, the development of extraction process that favors the both economic and technical aspects has been difficult.

Abbreviations: BR, bromelain; Carr, carrageenan.

* Corresponding author.

E-mail address: mpintado@porto.ucp.pt (M.M. Pintado).
Bromelain (BR) is a generic name given to proteolytic enzymes found in vegetable tissues such as peel, stem, fruit and leaves of the Bromeliaceae family, including pineapple stem (Ananas comosus). It is usually distinguished as either fruit BR (EC 3.4.22.33) or stem BR (EC 3.4.22.32) depending on its source, with all commercially available BR being derived from the stem. Stem and fruit BR have a molecular weight of $33 \mathrm{kDa}$ and $28 \mathrm{kDa}$ with an isoelectric point of 9.5 and 4.6, respectively [5]. The extract of BR has been shown to exhibit its activity over a pH range of 4.5-9.8.

This protease has wide range of applications in food and pharmaceutical industries. Recently, a wide range of therapeutic benefits have been attributed to BR such as the reversible inhibition of platelet aggregation, relief from bronchitis, improved recovery after surgical traumas, and the enhanced absorption of drugs, particularly of antibiotics [6]. One of the important pharmaceutical applications of BR is the enzymatic debridement of necrotic tissues from ulcers and burn wounds, as well as, medical treatment of cancer patients. Other pharmaceutical applications also described have been: antithrombotic, treatment of osteoarthritis and absorption promoter of antibiotic drugs [1]. 
In the food industry BR has been used as a meat tenderizing enzyme, but also in brewing and functional protein as pre-digestion and digestive support [6].

The traditional methods for the BR isolation have been through chemical precipitation, using ammonium sulphate at $50 \%$, acetone $80 \%$ and ethanol $60 \%[1,7]$. In these methods the recovery of BR activity is around $85 \%$ with a purification factor $3-4.90$. However, the precipitation with ethanol induce a decrease in the alpha helices content of BR [1] and a significant decreasing in the native fluorescence emission in agree with a loss of the secondary and tertiary structure and consequently on the activity [8]. The main problem of these methods is the use of high concentration of salt or solvents that in most cases cannot be discarded in the environment, so they must be recovery at the end of the process. In the case of ammonium sulphate the recovery of this high soluble salt is difficult, so an increase in the cost of the total process is implicit.

The biological precipitation can result in concentration and purification of BR maintaining good activity. Other advantages include easy scale-up, simple equipment and a large number of alternative precipitants; some of them are inexpensive or used at a very low concentration. Polysaccharides are precipitants that can interact with proteins, forming soluble or non-soluble complexes that, by changing medium conditions, such as $\mathrm{pH}$ or ionic strength, allow for the protein to be released, keeping its structure as well as its biological activity [9]. Carrageenan (Carr) is a family of polysaccharides obtained from certain species of red seaweeds (Rhodophyceae), non-toxic and water soluble. Carrageenans (Carr) are hydrophilic linear sulphated galactans, mainly consist of alternating 3-linked b-D-galactopyranose (G-units) and 4-linked a-D-galactopyranose (D-units) or 4-linked 3,6-anhydro-aD-galactopyranose (DA-units), forming disaccharide repeating unit of Carr. These polysaccharides are traditionally split into six basic forms, but the three commercial most important are Kappa ( $\kappa)-$, Iota ( $\mathrm{\iota})-$, Lambda $(\lambda)$ Carr, having one, two and three sulphate ester groups, respectively, corresponding to sulphate contents of 22, 32 and $38 \%(\mathrm{w} / \mathrm{w})$ [10]. Iota and kappa-Carr are gel-forming agents due a "crosslinking" spiral chains, double helix, with the sulphate groups oriented towards the external part [11].

The separation/purification of BR was never tested with success using a biological precipitation, thus in this work we have addressed the molecular mechanism of BR-Carr complex formation with the objective of designing a methodology (for) recovery and purification of stem BR throughout precipitation with ıcarrageenan.

\section{Materials and methods}

\subsection{Chemical}

Bromelain from the stem of Ananas comosus (BR), l-carrageenan (Carr), alpha- $N$-carbobenzyloxy-L-lysine $p$-nitro-phenyl ester (LNPE) and L-cysteine were purchased from Sigma-Aldrich (St. Louis, Missouri, USA), all the other reagents were of analytical quality from Cicarelli, laboratories (San Lorenzo, Argentina).

\subsection{Preparation of standard stem Bromelain}

Standard BR was prepared at a concentration of $100 \mathrm{mg} / \mathrm{mL}$ in $100 \mathrm{mM}$ sodium acetate buffer, $\mathrm{pH} 4.6,0.1 \mathrm{M}$ EDTA and $0.3 \mathrm{M}$ $\mathrm{KCl}$ were added to prevent enzyme degradation and improvement enzyme solubility as described by [8]. The solution was kept at $-18{ }^{\circ} \mathrm{C}$. To check eventual loss of protein structural integrity with the storage, measurement of enzyme activity was carried out before using.

\subsection{Determination of $B R$ activity}

BR activity was determined by using the substrate LNPE [12]. Briefly, the substrate was used in the assay at a final concentration of $0.23 \mathrm{mM}$ in buffer $30 \mathrm{mM}$ sodium acetate buffer, $\mathrm{pH} 4.6$, improved with $100 \mathrm{mM} \mathrm{KCl}$ and with $1.0 \mathrm{mM}$ of L-cysteine. The extent of the enzymatic reaction, represented by the release of $p$-nitrophenol, was measured spectrophotometrically for $5 \mathrm{~min}$ at $340 \mathrm{~nm}, 25^{\circ} \mathrm{C}$ and continuous stirring. One unit of enzymatic activity is the amount of BR that will release $1.0 \mathrm{~mol}$ of $p$-nitrophenol from LNPE in 1 min under the experimental conditions.

\subsection{Determination of total protein concentration}

It was carried out using the bicinchoninic assay (BCA) [13,14]. A fresh standard working reagent(SWR) was prepared mixing $100 \mathrm{vol}$ of reagent A (bicinchoninic acid solution; Sigma-Aldrich, St. Louis, Missouri, USA) with 2 vol. of reagent $\mathrm{B}\left(\mathrm{CuSO}_{4}\right.$ solution $4 \%(\mathrm{w} / \mathrm{v})$ prepared from $\mathrm{CuSO}_{4} \cdot 5 \mathrm{H}_{2} \mathrm{O}$; Sigma-Aldrich, St. Louis, Missouri, USA). A volume of $50 \mu \mathrm{L}$ of protein solution (maximum concentration of $1 \mathrm{mg} / \mathrm{mL}$ ) was added to $1 \mathrm{~mL}$ of SWR. The tubes were incubated at $37^{\circ} \mathrm{C}$ for $30 \mathrm{~min}$. After cooling down at room temperature, the absorbance was measured at $562 \mathrm{~nm}$ using a cell with a $1 \mathrm{~cm}$ path length. The calibration curve was performed using dilutions of a standard solution of bovine serum albumin $1 \mathrm{mg} / \mathrm{mL}$.

\subsection{Solubility diagram of BR-Carr complex}

Turbidity (absorbance at $420 \mathrm{~nm}$ ) of solutions of $3 \mathrm{mg} / \mathrm{mL}$ of BR with $0.1 \%(\mathrm{w} / \mathrm{v})$ of Carr was measured and plotted against $\mathrm{pH}$. The $\mathrm{pH}$ variations of the medium were obtained by adding $\mathrm{NaOH}$ or $\mathrm{HCl}$ aliquots and leaving the $\mathrm{pH}$ of the system to equilibrate before measuring the turbidity. These titration curves were made in order to estimate the $\mathrm{pH}$ range where the protein-polymer complex is soluble or non-soluble $[9,12]$.

\subsection{Turbidimetric titration curves with Carr}

The formation of the insoluble BR-Carr complex was monitored by means of turbidimetric titration. A fixed BR concentration $(3 \mathrm{mg} / \mathrm{mL}$ ) in $30 \mathrm{mM}$ acid acetic/acetate buffer $\mathrm{pH} 4.6$ was titrated at $25^{\circ} \mathrm{C}$ in a glass cell using Carr solution as titrant. To avoid changes in $\mathrm{pH}$ during titration, both BR and Carr solutions were adjusted to the same $\mathrm{pH}$ value. The absorbance of solution at $420 \mathrm{~nm}$ was used to follow the BR-Carr complex formation and plotted vs. the total Carr concentration in the tube. The results were fitted with a 4-parameters sigmoidal function in order to determine the value of the Carr minimal concentration required to precipitate BR. This parameter was calculated as the intersection of the tangent at the inflection point with the plateau of the plot. The $[\mathrm{BR}] /[\mathrm{Carr}]$ ratio can be calculated as the ratio between the BR total concentration and the [Carr] calculated. Absorbance solutions were measured using a Jasco 520 spectrophotometer (Jasco Analytical Instruments, Washington, USA) with constant agitation in a thermostatized cell of $1 \mathrm{~cm}$ of path length [12].

\subsection{Zeta potential and size of the complexes particles}

A Zetasizer Nano ZSP (Malvern Instruments, Worcestershire, UK) using dynamic light scattering (DLS) was used to measure the particle size (PS) and $\xi$-potential (ZP). The complex BR-Carr stock solutions were produce in $30 \mathrm{mM}$ acetate buffer, the $\mathrm{pH}$ was adjusted by adding aliquots of $\mathrm{NaOH}$ for $\mathrm{pH}$ increase and $\mathrm{HCl}$ to decrease $\mathrm{pH}$, varying from 9.0 to 1.0 by 0.5 unit increments with a confidence interval of \pm 0.1 unit. Particle sizes (hydrodynamic radius) were measured by taking into account the first order result 
from a DLS experiment as an intensity distribution of PS. The intensity distribution was weighted according to the scattering intensity of each particle fraction or family. Data were validated only if the cumulant fit error was $<0.005$. $\xi$-potential was measured using Laser Doppler Anemometry (LDA). All analyses were carried out three times and sample readings were done in triplicate with an angle of $90^{\circ}$ at $25^{\circ} \mathrm{C}$.

\subsection{Thermal stability of BR and BR-Carr complex}

The thermal stability of BR and complex BR-Carr was measure by the native fluorescence emission of the protein at $350 \mathrm{~nm}$. The samples were exposed to a temperature gradual increase between 25- $90^{\circ} \mathrm{C}$, every $5{ }^{\circ} \mathrm{C}$ were taken samples and the BR activity and the relative fluorescence emission were measured. The data analysis was made assuming an approximation of two-state model of denaturation ( $\mathrm{N}$ : native and $\mathrm{D}$ : denatured) where only the native and unfolded states were significantly populated.

Being $\mathrm{K}$, the equilibrium constant, it can be written as:

$K=\frac{[D]}{[N]}$

The unfolded protein fraction was calculated as:

$\alpha=\frac{F \mathrm{i}-F D}{F N-F D}$

Where: $\alpha$ is the unfolded protein fraction, $F_{N}$ and $F_{D}$ are the fluorescence emission of the native and unfolded states respectively, $\mathrm{F}_{\mathrm{i}}$ is the fluorescence at any temperature. We have used non-linear least squares to fit the unfolded protein fraction versus temperature data, and the temperature at the mid-point of denaturation $\left(\mathrm{T}_{\mathrm{m}}\right)$ was determined. The equilibrium constant, $\mathrm{K}$, for the unfolding process can be calculated:

$K=\frac{\alpha}{1-\alpha}$

From the following equation the free energy $\left(\Delta G^{\circ}\right)$ of the denaturation process can be calculated as:

$\Delta G^{\circ}=-R T \ln K$

And the enthalpy change $\left(\Delta H^{\circ}\right)$ from equation:

$\frac{\partial \ln K}{\partial T}=-\frac{\Delta H}{T}$

Finally, the entropic change $\left(\Delta S^{\circ}\right)$ of the unfolding process vs temperature can be calculated as:

$\Delta G=\Delta H-T \Delta S$

\section{Results and discussion}

\subsection{Solubility phase diagrams of BR-Carr complex}

Complex formation between Carr and BR as function of $\mathrm{pH}$ was determined as shown in Fig. 1 (insert). The formation of complex was observed (a constant protein/polymer ratio) to be dramatically influenced by the $\mathrm{pH}$ of medium. The increase in $\mathrm{pH}$ above 5.0 induced a dramatic increase in the turbidity, with a maximum at $\mathrm{pH}$ 5.1. At higher $\mathrm{pH}$ values the turbidity decreased according with the solubilisation of the non-soluble complex. Carr has negative electrical charge at $\mathrm{pH} 2$ due to the presence of strong acidic groups (sulphonic), while BR (isoelectrical pH 9.6) has positively electrical charge in acid $\mathrm{pH}$; the positive electrical change of the $\mathrm{BR}$ decreases as the $\mathrm{pH}$ increases and diminution of the turbidity is observed due a minor formation of BR-Carr complex. In the acid range of the curve (left) the decrease in the turbidity should be due to partial protonation of some sulphonic groups of Carr, which

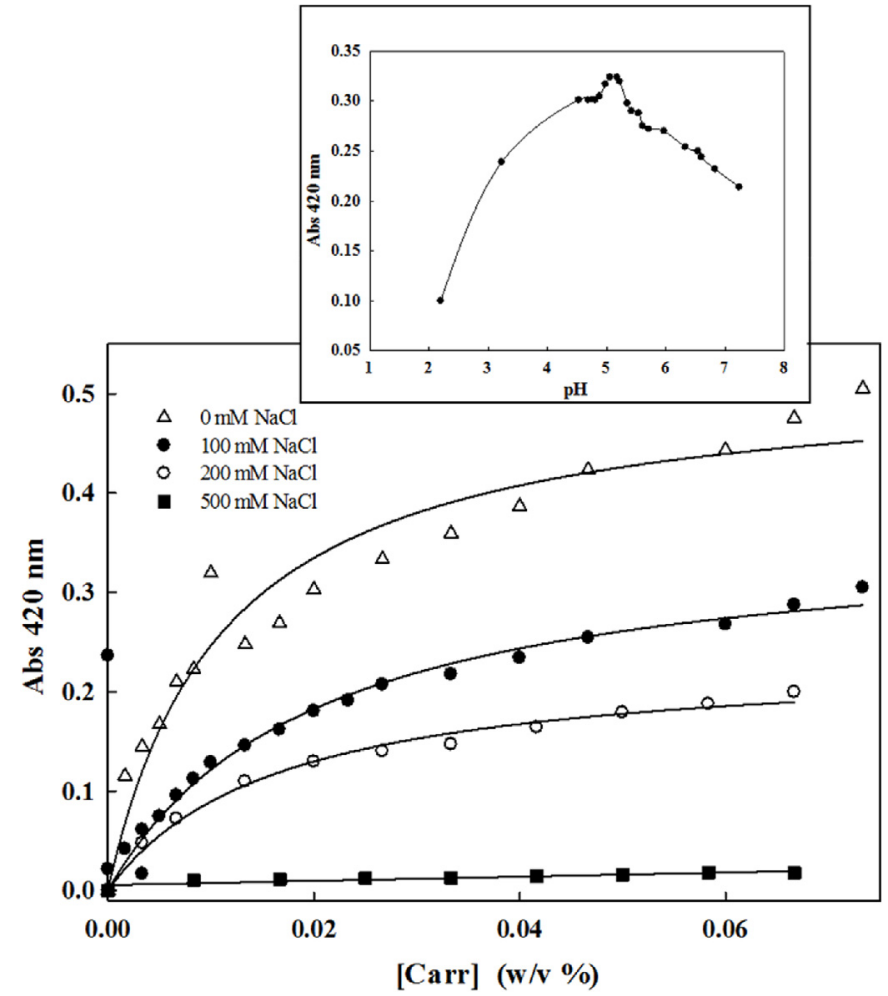

Fig. 1. Titration of $B R$ with increasing concentration of Carr, at different concentrations of $\mathrm{NaCl}(0,100,200$ and $500 \mathrm{mM})$. Inset: turbidimetric evaluation of complex formation. Medium: $25 \mathrm{mM}$ acetate buffer, $\mathrm{pH} 5.1$. BR concentration of $3 \mathrm{mg} / \mathrm{mL}$. Enzyme activity was measured at $\mathrm{pH}$ 5.1.

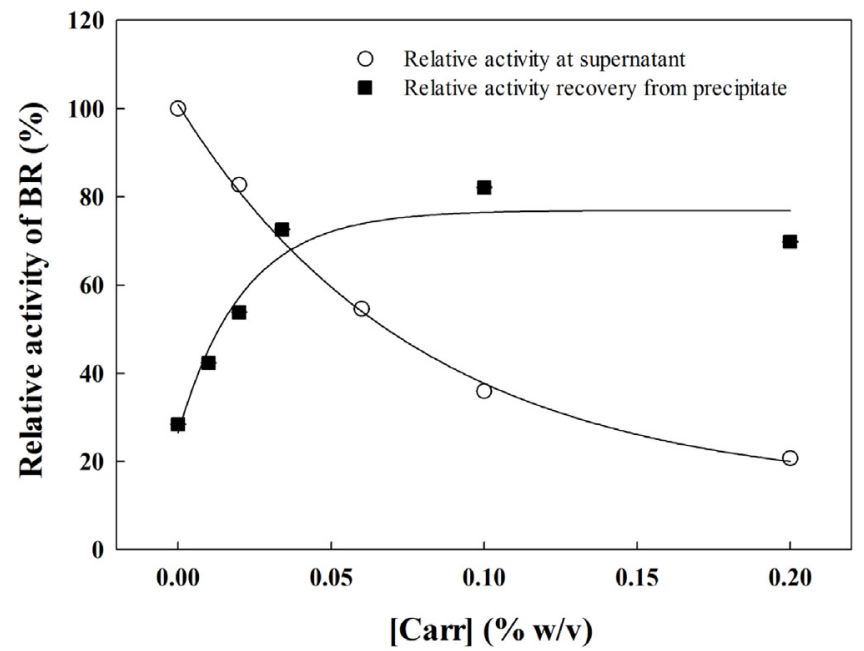

Fig. 2. Recovery of BR and activity measurement in the precipitate and in the supernatant at different initial concentrations of Carr. Medium: $25 \mathrm{mM}$ acetate buffer, $\mathrm{pH}$ 5.1. BR concentration of $3 \mathrm{mg} / \mathrm{mL}$. Enzyme activity was measured at $\mathrm{pH} 5.1$.

induces a loss of negative electrical charge density on the polymer chain [9]. Fig. 1 shows the variation of the medium absorbance at $420 \mathrm{~nm}$ when BR was titrated with Carr at pH 5.1 at different ionic strengths. The Abs values increased until a constant value (plateau) indicating a higher extent of complex formation. The salt presence increases the solubility of the complex, as it was observed by the decrease of the turbidity, being completely null at $500 \mathrm{mM}$ of $\mathrm{NaCl}$. Taking this into account, the interaction of BR with Carr seems to be only of columbic in nature. From these curves, was possible calculate the minimal optimal Carr amount needed to precipitate BR, which corresponds to the case in which most BR has been precip- 

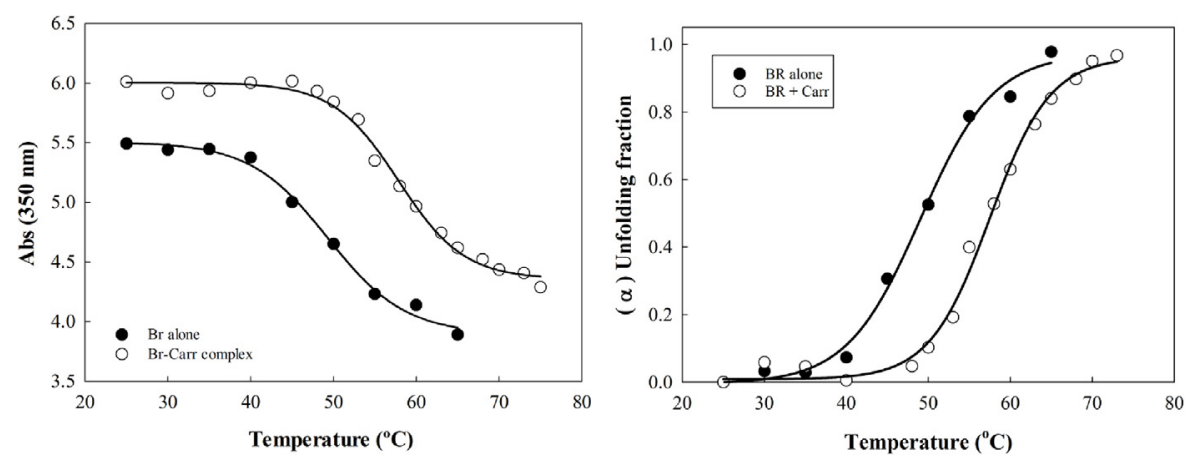

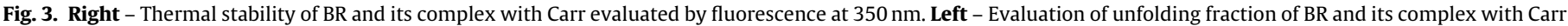
Medium: $25 \mathrm{mM}$ acetate buffer, $\mathrm{pH} 5.1$. BR at $3 \mathrm{mg} / \mathrm{mL}$ and Carr at $1.5 \mathrm{mg} / \mathrm{mL}$.

itated as an insoluble complex - from the fitting data of Fig. 1 the stoichiometry ratio was $3.0 \mathrm{mg}$ protein $/ 0.01 \mathrm{mg}$ polymer (being the minimal Carr concentration necessary to precipitate the BR around $0.005 \% \mathrm{w} / \mathrm{v}$ ). This finding shows that the Carr concentration needed to precipitate BR was very low, when compared to other traditional proteins precipitation methods, using inorganic cations and anions, demonstrating a high potential for the scale up of the method. In many cases, the target proteins are present in high volumes of solution, but even so, a small mass of this polyelectrolyte is necessary to precipitate the enzyme.

A complementary experiment to confirm that Carr presence does not modifies the biological activity of BR was performed. A constant concentration of BR was incubated with increasing Carr concentration, at $\mathrm{pH} 4.6$, during $30 \mathrm{~min}$ and then the non-soluble complex was separated by centrifugation and re-dissolved in Tris$\mathrm{HCl}$ buffer, pH 8.2 with addition of $500 \mathrm{mM}$ of $\mathrm{NaCl}$. Finally, the enzymatic activity of BR was determined in the supernatant and in the re-dissolved precipitate, the results are shown in Fig. 2. In average around $80 \%$ of the activity was recovered, in the solubilized precipitate, while $20 \%$ of the activity remained in the supernatant confirming that the following equilibrium is displaced in a large extent to non-soluble complex formation:

$B R(a q)+\operatorname{Carr}(a q) \leftrightarrow B R-\operatorname{Carr}(p p)$

This experiment validates the viability of this method as a technique for the separation of BR.

\subsection{Emission of the native fluorescence of $B R$ in the presence and absence of Carr}

Fluorescence emission of proteins is dominated by tryptophan, which absorbs at the longest wavelength (in water, $350 \mathrm{~nm}$ ). Effect of Carr on protein structure was monitored using fluorescence spectroscopy [15]. The emission spectra of BR in buffer acetate pH 5.1 in the absence and the presence of Carr $(0.034 \% \mathrm{w} / \mathrm{v})$ was obtained (data not shown). The presence of Carr did not affect the fluorescence spectrum, which means that the polysaccharide did not change the microenvironment of tryptophan residues presents in BR. On the other hand, Rocha and Nerli [8] have studied the isolation of BR using an aqueous two-phases system using polyethylenglycols (PEGs) of different molecular weights and reported the changes of fluorescence on the emission spectra of BR, which indicates the changes on the microenvironment of tryptophan residues.

\subsection{Thermal stability of the BR in the Carr presence}

The effect of the temperature on the enzyme in the absence and presence of Carr was assayed by measuring the native fluorescence
Table 1

Thermodynamic thermal stability parameters of BR and its complex. Medium: $25 \mathrm{mM}$ acetate buffer, $\mathrm{pH}$ 5.1. Enzyme concentration $3 \mathrm{mg} / \mathrm{mL}$ and polysaccharide at $1.5 \mathrm{mg} / \mathrm{mL}$.

\begin{tabular}{lllll}
\hline System & $\operatorname{Tm}\left({ }^{\circ} \mathrm{C}\right)$ & $\Delta \mathrm{H}^{\circ}(\mathrm{Kcal} / \mathrm{mol})$ & $\Delta \mathrm{S}^{\circ}($ e.u. $)$ & $\left(\partial \alpha^{\prime \prime} / \partial \mathrm{T}\right)_{0.5}$ \\
\hline BR alone & $49.3 \pm 0.8$ & 13.9 & 43.1 & 4.48 \\
BR-Carr & $57.8 \pm 0.4$ & 50.8 & 153.0 & 3.67 \\
\hline
\end{tabular}

emission of BR at $350 \mathrm{~nm}$ vs. temperature as shown at Fig. 3. The thermal pattern of Fig. 3 shows that the presence of Carr induces a thermodynamic stabilization of BR since an increase in the $T_{m}$ values was observed as shown at Table 1 . These results are encouraging since BR seems to be stable over a significant increment of temperature in medium with Carr. This fact comes unsurprisingly, since it is known that the addition of co-solutes such as polysaccharides and other hydrophilic substances to a protein solution leads to an enhanced structural stability [16].

Table I show the calculated values of $\Delta H$ and $\Delta S$ for BR unfolding in absence and presence of Carr. The entropic and entalphic changes were positive and consistent with the published results for protein denaturation. The inflection point of the thermal unfolding curves $\left((\partial \alpha \breve{n} / \partial T)_{0.5}\right)$ gives an idea of the cooperativity between protein-polysaccharide at the unfolding process and how the polysaccharide presence changes this process. The values were calculated as explained above and are described at Table I.

It can be seen that the polymer presence induced a decrease in the cooperative factor suggesting a diminution in the response of the enzyme to the thermal change by the Carr presence.

\subsection{Effect of $p H$ on size and zeta potential of BR in the absence and presence of Carr}

The Fig. 4 shows the pH effect at the complex formation of BR in presence of Carr. The Hydronamic radius (Hd) was evaluated, as well as, the intensity percentage of the complexes formation. A Hd pick of $17.5 \pm 0.1 \mathrm{~nm}$ and intensity pick of $84 \%$ was achieved for a $\mathrm{pH}$ between 4.6 and 4.8 , this value converted at molecular weight correspond to $541 \pm 12 \mathrm{kDa}$, which was indicative of complexes formation, since BR alone has a theoretical value of $33 \mathrm{kDa}$ and Carr between 400 and $600 \mathrm{kDa}$ (polydisperse molecular weight), thus the Hd pick obtained was the protein-polysaccharide complex. For $\mathrm{pH} \geq 5$ it was observed a Hd group of $7 \mathrm{~nm}$ (around $80 \mathrm{kDa}$ ) and for $\mathrm{pH} \geq 6.7$ these Hd groups disappeared completely, these values keep up with intensity, indicating the complete dissolution of complex. On the other hand, for $\mathrm{pH} \leq 4.5$ the Hd values decrease to $6.0 \pm 0.2 \mathrm{~nm}$, corresponding to $35 \pm 2 \mathrm{kDa}$, which shows the protein free in solution. It was clear, that $\mathrm{pH}$ modifies the complex formed in quantity and quality. Two critical $\mathrm{pH}(\mathrm{pHc})$ of complex formation 


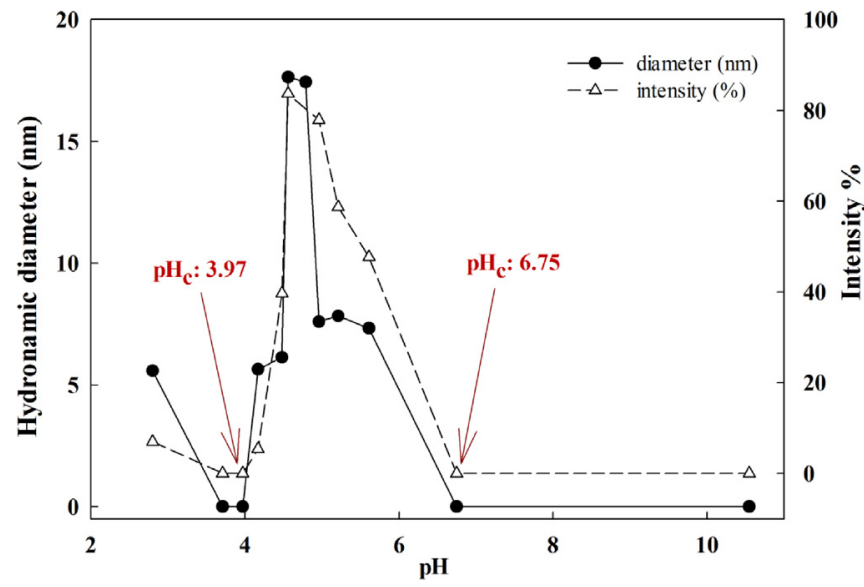

Fig. 4. Hydronamic diameter and intensity of Br-Carr complex formation in an acidbase titration at $0 \mathrm{mM} \mathrm{NaCl}$. Critical $\mathrm{pH}$ at left of 3.97 and at right 6.75. Medium: $25 \mathrm{mM}$ acetate buffer. BR concentration of $3 \mathrm{mg} / \mathrm{mL}$ and Carr at $1.5 \mathrm{mg} / \mathrm{mL}$.

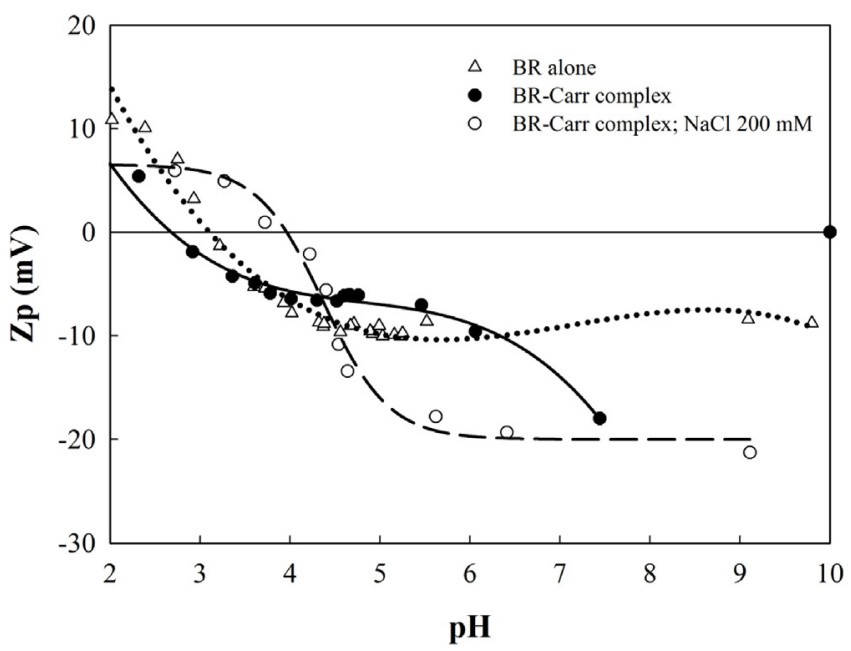

Fig. 5. Acid-base titration of $B R$ and BR-Carr complex at $0 \mathrm{mM} \mathrm{NaCl}$ and at $200 \mathrm{mM}$ $\mathrm{NaCl}$, evaluation of zeta potential (mV) by Dynamic light scattering. Medium: $25 \mathrm{mM}$ acetate buffer, initial pH 4.5. BR concentration of $3 \mathrm{mg} / \mathrm{mL}$ and Carr at $1.5 \mathrm{mg} / \mathrm{mL}$.

were obtained with the acid-base titration curve, $\mathrm{pH} 3.97$ and 6.75 , being between these values the range of non-soluble complex formation. The complex formation involves the interaction between proteins and polysaccharides, and in some cases even hundreds of proteins could be bonded to just one polysaccharide molecule. These connections at the complex could be unbounded by shifting $\mathrm{pH}$ and ionic strength of the medium. The formation of the soluble complex can be followed by light scattering measurements by measuring Zp (charges measure at the medium) shown in Fig. 5 and the $\mathrm{Hd}$ in Fig. 4. In a second step, an interaction is produced between the soluble complex particles and a non-soluble complex (of high molecular mass) is produced being this second step is easily followed by turbidimetry (measuring the absorbance of the medium at $420 \mathrm{~nm}$, Fig. 1 - insert). Finally, the non-soluble particles interact between them to form a macro-aggregate state complex [17].

Fig. 5 shows the dependence of the Zp of BR in the absence and presence of Carr and $\mathrm{NaCl} 200 \mathrm{mM}$. It has been reported that stem and fruit BR have a molecular weight of $33 \mathrm{kDa}$ and $28 \mathrm{kDa}$ with an isoelectric point of 9.5 and 4.6 , respectively. The extract of commercial BR used in this work is from stem, however, both BR are present. This can be observed from the data $\mathrm{Zp}$ vs pH (from Fig. 5) where the $\mathrm{Zp}$ value of BR-Carr complex decreased respect to the free BR, due to neutralization of the residual positive electrical charge of $B R$.
However, in the presence of $\mathrm{NaCl} 200 \mathrm{mM}$, the Zp of the complex increased due to screening of the electrical charge by the salt.

This was due to the interaction between soluble complexes that interacts with the medium at low electrical charge, so the attraction forces are major than the repulsion ones. Hence, the increasing of $\mathrm{pH}$ does not increase the number of negative electrical charge of the Carr, but a loss of positive charges of BR and consequently the balance between the positive and negative charges were not compensated and the complexes increased negatively, which induces repulsion between the particles of complex of minor mass. As result, a diminution of the diameter of the complexes was observed, with its existence occurring at a higher $\mathrm{pH}$ interval.

\section{Conclusion}

The use of natural polysaccharides electrically charged (polyelectrolytes) as precipitant agents by formation of non-soluble complexes, where the enzyme can be recovered by inversion of the conditions such as change of the medium $\mathrm{pH}$ or low salt concentration, is an advantage on the traditional methods. It was found that Carr does not modify the biological activity of the BR and increases the thermal stability of the enzyme around $8^{\circ} \mathrm{C}$. It was demonstrated for the first time in this research work that the natural polyelectrolyte Carr allows to precipitate BR under a nonsoluble complex, which can be re-dissolved and recovered by slight changes in medium variables, such as, the $\mathrm{NaCl}$ concentration and $\mathrm{pH}$ values. Also, it was proved that BR maintained its biological activity (yield of activity was $80 \%$ at precipitate) through the precipitation process, since Carr also acted as enzyme stabilizer and above of all is a nontoxic and a food grade low cost polysaccharide. The complex formation and precipitation method showed to be suitable for BR purification.

\section{Acknowledgments}

The work was financially supported by BiValBi - Biotechnologies to Valorise the regional Biodiversity in Latin America, FCT - Fundação para a Ciência e a Tecnologia through project UID/Multi/50016/2013 and by PhD grant SFRH/BD/104074/2014 to Débora Campos.

\section{References}

[1] P.A. Soares, A.F. Vaz, M.T. Correia, A. Pessoa, M.G. Carneiro-da-Cunha, Purification of bromelain from pineapple wastes by ethanol precipitation, Sep. Purif. Technol. 98 (2012) 389-395.

[2] M.A. Desai, Downstream Processing of Proteins: Methods and Protocols, Springer Science \& Business Media, 2000.

[3] H.-J. Bart, S. Pilz, Industrial Scale Natural Products Extraction, John Wiley \& Sons, 2011.

[4] R. Hatti-Kaul, B. Mattiasson, Isolation and Purification of Proteins, CRC Press, 2003.

[5] T. Harrach, K. Eckert, K. Schulze-Forster, R. Nuck, D. Grunow, H.R. Maurer, Isolation and partial characterization of basic proteinases from stem bromelain, J. Protein Chem. 14 (1) (1995) 41-52.

[6] A. Amid, N.A. Ismail, F. Yusof, H.M. Salleh, Expression, purification, and characterization of a recombinant stem bromelain from Ananas comosus, Process Biochem. 46 (12) (2011) 2232-2239.

[7] R.S. Chaurasiya, H.U. Hebbar, Extraction of bromelain from pineapple core and purification by RME and precipitation methods, Sep. Purif. Technol. 111 (2013) 90-97.

[8] M.V. Rocha, B.B. Nerli, Molecular features determining different partitioning patterns of papain and bromelain in aqueous two-phase systems, Int. J. Biol. Macromol. 61 (2013) 204-211.

[9] N.W. Valetti, J. Lombardi, V. Boeris, G. Picó, Precipitation of chymotrypsin from fresh bovine pancreas using -carrageenan, Process Biochem. 47 (12) (2012) 2570-2574.

[10] G.A. De Ruiter, B. Rudolph, Carrageenan biotechnology, Trends Food Sci. Technol. 8 (12) (1997) 389-395.

[11] C. Morais, J. VALLE, A. Pizzinatto, Coloides de algas marinhas. 1l, Considerações Sobre as Carragenanas, Colet. ITAL 19 (1) (1989) 12-24. 
[12] R. Heinrikson, Acidic cysteine protease inhibitors from pineapple stem, Methods Enzymol. 45 (1976) 740-751.

[13] J.M. Walker, The bicinchoninic acid (BCA) assay for protein quantitation, in: The Protein Protocols Handbook, 2009, pp. 11-15.

[14] R.E. Brown, K.L. Jarvis, K.J. Hyland, Protein measurement using bicinchoninic acid: elimination of interfering substances, Anal. Biochem. 180 (1) (1989) $136-139$

[15] J.R. Lakowicz, Topics in Fluorescence Spectroscopy: Volume 4: Probe Design and Chemical Sensing, Springer Science \& Business Media, 1994.
[16] R. Chaiklahan, N. Chirasuwan, B. Bunnag, Stability of phycocyanin extracted from Spirulina sp.: influence of temperature, $\mathrm{pH}$ and preservatives, Process Biochem. 47 (4) (2012) 659-664.

[17] V. Boeris, L.V. Cappella, G. Peres, I. Burgos, N.P. Da Silveira, G. Fidelio, G. Picó, Chymotrypsin-Eudragit complex formation, Biotechnol. Bioprocess Eng. 18 (3) (2013) 538-545. 